\title{
Beyond protection: Delineating the economic and food production potential of underutilized, small-parcel farmland in metropolitan Surrey, British Columbia
}

\author{
Kent Mullinix, ${ }^{*}$ Caitlin Dorward, ${ }^{a}$ Marc Shutzbank, ${ }^{a}$ Parthiphan Krishnan, ${ }^{b}$ Karen \\ Ageson, ${ }^{a}$ and Arthur Fallick ${ }^{a}$ \\ Kwantlen Polytechnic University
}

Submitted May 31, 2013 / Revised August 6, 2013 / Accepted August 6, 2013 / Published online December 4, 2013

Citation: Mullinix, K., Dorward, C., Shutzbank, M., Krishnan, P., Ageson, K., \& Fallick, A. (2013). Beyond protection: Delineating the economic and food production potential of underutilized, small-parcel farmland in metropolitan Surrey, British Columbia. Journal of Agriculture, Food Systems, and Community Development, 4(1), 33-50.

http://dx.doi.org/10.5304/jafscd.2013.041.005

Copyright (C) 2013 by New Leaf Associates, Inc.

\begin{abstract}
Surrey, British Columbia, is Canada's twelfth largest and fastest-growing city. Within its boundary, 8,692 hectares (21,478 acres) (25 percent of the municipality's land base) are protected by the province's Agricultural Land Reserve (ALR). Local government intuits the long-term importance of ALR lands. In this region speculative land development for urbanization is routinely considered the greatest threat to agriculture land loss. However, our analyses reveal that use of ALR land in Surrey

\footnotetext{
a Institute for Sustainable Food Systems, Kwantlen Polytechnic University, Surrey, B.C. Canada

${ }^{\mathrm{b}}$ Department of Geography, Kwantlen Polytechnic University, Surrey, B.C., Canada

* Corresponding author: Kent Mullinix, Institute for Sustainable Food Systems, Kwantlen Polytechnic University, 12666 72 ${ }^{\text {nd }}$ Avenue, Surrey, British Columbia, V3W 2M8 Canada; +1-604-612-1252; kent.mullinix@,kwantlen.ca

Note: Funding for this study was provided by the City of Surrey, British Columbia. The authors would like to acknowledge and thank Karen Taylor, PhD, formerly of Farm Credit Canada, for reviewing study methods and calculations.
}

for non-agricultural purposes was the greatest contributor to "effective agricultural land loss" and thus poses a formidable threat to ALR diminution. Given that most of these underutilized parcels are less than 5 hectares (12.4 acres) in size, the Surrey government is interested in the potential of smalllot, community-focused agriculture to curtail their loss from agriculture while simultaneously contributing to community economic vitality. We conducted an inventory of 669 properties, covering 3,035 hectares $(7,500$ acres $)$ or approximately 33 percent of the total Surrey ALR, which had been identified as underutilized for agriculture by the Ministry of Agriculture in its 2004 City of Surrey Agricultural Land Use Inventory. Our work revealed that at least 556 parcels amounting to 2,446 hectares (6,044 acres) (27 percent of Surrey's ALR) remained underutilized, and that within these parcels 1,351 hectares (3,338 acres) (15 percent) could still conceivably be farmed. We calculated that if brought into small-scale, human-intensive, direct-market production, these lands could satisfy 100 percent of Surrey's seasonal consumption of 29 regionally appropriate crop and animal 
products, create over 1,500 jobs, and have the potential to nearly double the current economic magnitude of Surrey's agriculture sector.

\section{Keywords}

Agricultural Land Reserve, agricultural land speculation, direct-market agriculture, humanintensive agriculture, metropolitan agricultural land, small-lot agriculture, underutilized agricultural land, urban encroachment

\section{Acronyms Used}

ALC: Agricultural Land Commission

ALR: Agricultural Land Reserve

ARA: agriculture-related activity

BC: British Columbia (Canada)

FTE: Full-time equivalent

FTEFL: Full-time equivalent-field labor

FTEOO: Full-time equivalent-owner/operator

GVRD: Greater Vancouver Regional District

\section{Introduction}

Surrey, British Columbia, Canada, has a long and significant agricultural history. In the late 1800s the city grew up amid pioneer family farms which had been established in the fertile lowlands of the Nicomekl and Serpentine rivers (figure 1).

These early farms produced a wide variety of agricultural products and played a key role in what was then a relatively regional agrifood system reliant on rail and shipping to transport goods to markets in southwest and eastern British Columbia (B.C.) and Vancouver Island. By 1940, a new bridge and highway connected Surrey to neighboring southwest British Columbia municipalities, initiating a period of rapid suburban development enabled by the conversion of much of Surrey's farmland into residential neighborhoods. This trend was also occurring in surrounding areas; during this period as much as 6,000 hectares $(14,826$ acres $)$ of prime agricultural land, predominantly in southwest British Columbia, were lost annually to (primarily) urban and suburban uses (British Columbia Provincial Agricultural Land Commission, 2002a). Urban development of farmland continued unabated until 1973, when the provincial government introduced the Agricultural Land Commission (ALC) Act (B.C. Provincial Agricultural Land Commission 2002b) with the objective of protecting threatened farmland in perpetuity. The act resulted in the creation of the Agricultural Land Reserve (ALR), a "provincial zone in which agriculture is recognized as a priority

\section{Figure 1. Metro Vancouver, B.C., with City of Surrey Highlighted}

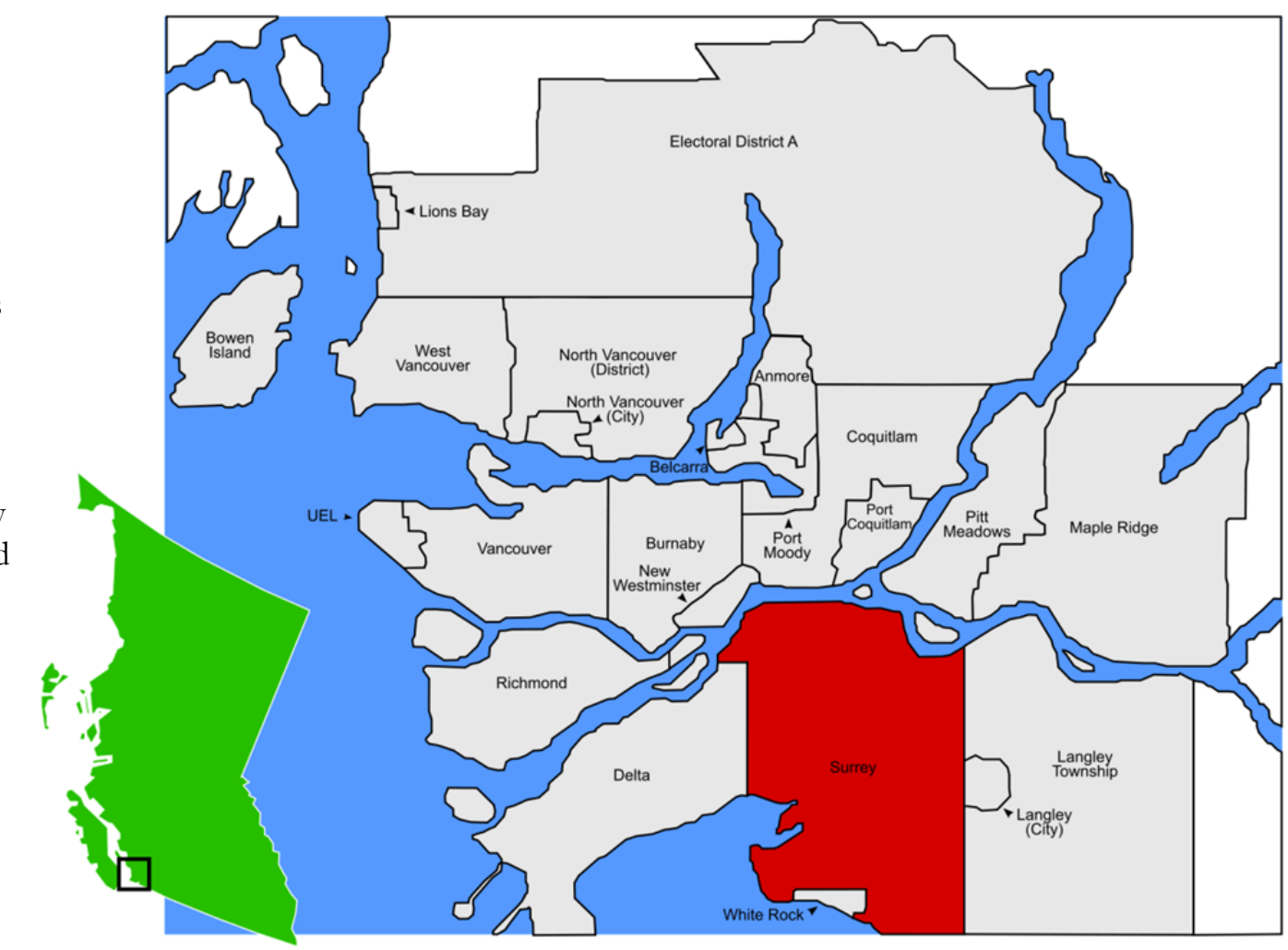


use, farming is encouraged, and non-agricultural uses are controlled" (B.C. Provincial Agricultural Land Commission, 2002a, para. 1;). Prior to the act, extensive subdivision of agriculture lands into small parcels (e.g., 2 hectares or 5 acres) occurred. It may be that subdivision of agricultural lands, as well as encroachment, motivated the legislation. This has encouraged profligate establishment of rural residences and various non-farm ALR land use, especially in peri-urban regions such as metroVancouver. It has also been observed that the ALR has functioned as a de facto urban growth boundary in B.C., and in metropolitan areas (especially) the ALR has not curtailed speculative land holding (Condon, Mullinix, Fallick, \& Harcourt, 2010). In the City of Surrey, approximately 8,787 hectares (21,713 acres) were designated as part of the ALR. These lands, part of the Pacific Maritime Eco-zone that extends along Canada's Pacific Coast, typically have over 200 frost-free days (the most in Canada) due to the influences of the ocean (Agriculture and Agri-Food Canada, 2013a; Environment Canada, 2012). Surrey receives on average $1050 \mathrm{~mm}$ (41.3") of precipitation annually and has an average summer temperature of $22^{\circ} \mathrm{C}\left(72^{\circ} \mathrm{F}\right)$. Gleysolic and Organic-Fibrisol soils dominate Surrey's agricultural lands, where organic materials accumulate around the surface area of the clay within the soil. With proper drainage these soils are considered prime agricultural land due to their high nutrient content (Agriculture and Agri-Food Canada, 2013b).

Eventually Surrey, Vancouver, 20 other nearby municipalities, several Indian Reserves, and one Electoral Area formed the Greater Vancouver Regional District. This regional district is now called Metro Vancouver, and is western Canada's major metropolis. Between 2006 and 2011 Metro Vancouver absorbed about 69 percent of British Columbia's population growth and now has a population of 2.44 million. This was the second highest population growth rate among metropolitan areas in Canada. Within Metro Vancouver, the City of Surrey exhibited the highest growth rate during the most recent census period, and is now home to 19 percent of the province's population $(468,251)$. This has placed enormous development pressure on agricultural lands and resulted in a situation in which the real estate value of ALR land is far in excess of that justified by any form of production agriculture (Condon et al., 2010). In economic terms, the opportunity cost of ALR land being used for agricultural purposes is too high.

The nature of a jurisdiction's agriculture sector can profoundly influence its economic, social, and civic character (Goldschmidt, 1978; Nassauer, 1997). Surrey's extensive agricultural lands, which run geographically north-south through the heart of this suburban but very rapidly urbanizing municipality, are a unique feature and prompt many to describe Surrey as having a dual "urban and rural" character (figure 2). Surrey's 9,000 hectares (22,239 acres) of ALR lands currently make up approximately 25 percent of the city's total jurisdictional area and account for about 15 percent of all the agricultural land in Metro Vancouver (B.C. Ministry of Agriculture and Lands, Sustainable Agriculture Management Branch, 2009). Agriculture remains an important component of Surrey's municipal landscape; however, farm numbers in the municipality are steadily declining. The number of census-reporting farms has declined by approximately 30 percent over the past 20 years (Metro Vancouver, 2007). Surrey's current agriculture sector produces a wide variety of crops and products (table 1), generates over CA $\$ 153$ million in gross annual farm receipts, employs approximately 4,470 people, and pays over CA $\$ 37$ million in wages (City of Surrey Economic Development Office, n.d.).

In 2006, average gross receipts on Surrey farms were $C A \$ 314,971$, which is higher than the average for both Metro Vancouver farms (CA $\$ 278,306)$ and B.C. farms (CA $\$ 133,641)$ (B.C. Ministry of Agriculture and Lands, Sustainable Agriculture Management Branch, 2009). The higher average gross farm receipts are due largely to farms producing commodities under the province's Supply Management program, which regulates production through a quota system and sets wholesale prices (Hamilton, 2011). Eggs, poultry, and dairy are the Supply Managed commodities. Otherwise 46 percent of Surrey agriculture operations (226 farms) report gross receipts of less than $\mathrm{CA} \$ 10,000$, reflecting a high incidence of minimally lucrative farm operations (Boyd, 1998; B.C. 
Figure 2. ALR Boundary and Municipal Agriculture Zones in Surrey, B.C.

\section{Legend}

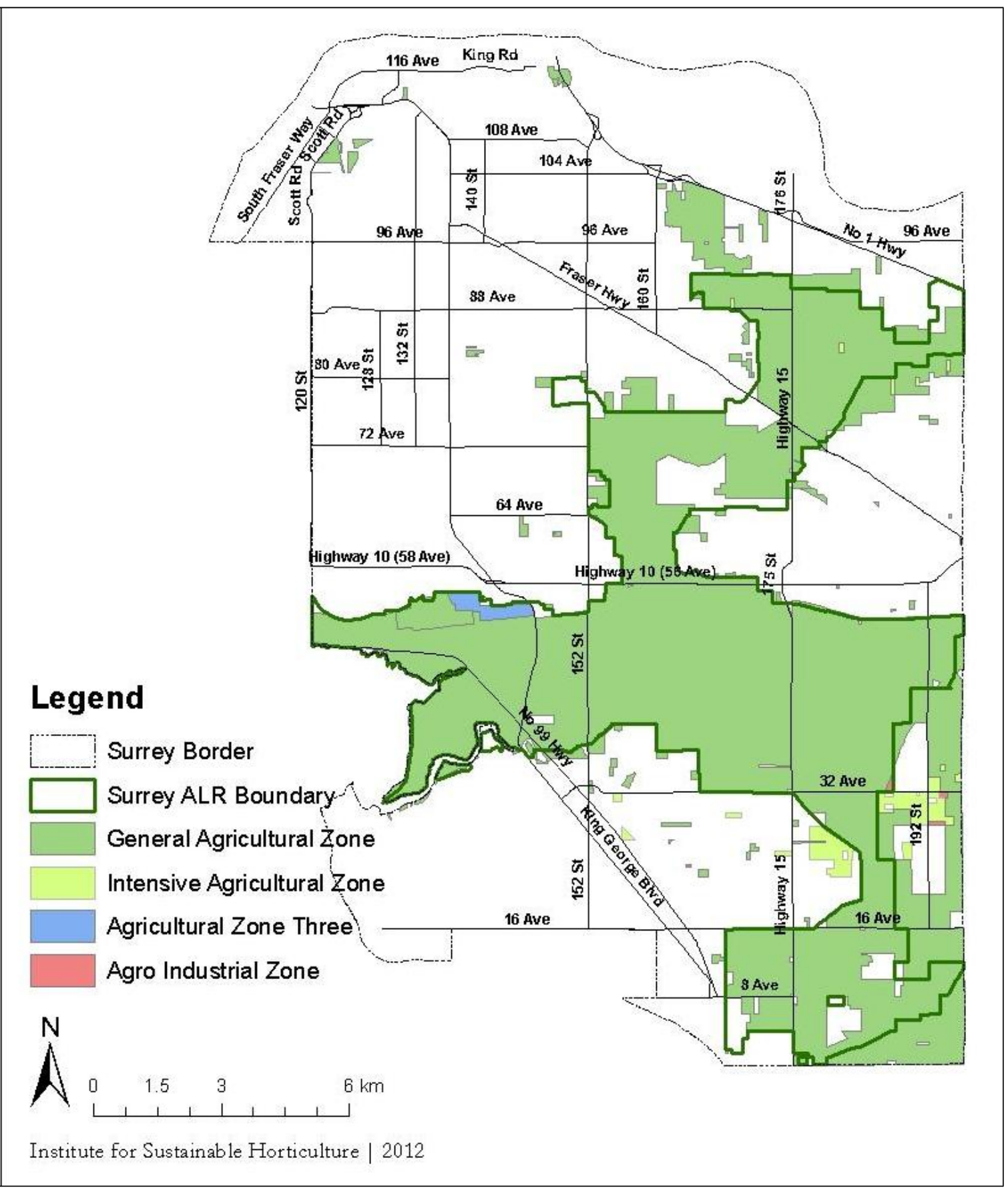

Ministry of Agriculture and Lands, Sustainable Agriculture Management Branch, 2009; Morton, 2008).

The City of Surrey, like other jurisdictions in southwest B.C. and elsewhere, is demonstrably committed to preserving its farmlands and supporting the agri-food sector, including local production and supply (Cantrell, Colasanti, Goddeeris, Lucas, \& McCauley, 2013; City of Surrey, 2008a; District of Maple Ridge, 2009; Esseks, Oberholtzer, Clancy, Lapping, \& Zurbrugg, 2008; Kent Agricultural Advisory Com- 
Table 1. Agricultural Land Use Activities on ALR Land in Surrey, BC (2006)

\begin{tabular}{|c|c|c|c|}
\hline Agricultural Land Use Activity & $\begin{array}{l}\text { Number of } \\
\text { Parcels }\end{array}$ & $\begin{array}{l}\text { Total Area } \\
\text { (ha | acre) }\end{array}$ & $\begin{array}{l}\text { Percent of Surrey } \\
\text { ALR in this Use }\end{array}$ \\
\hline Forage and Pasture & 226 & $1,934 \mid 4,779$ & $22 \%$ \\
\hline Berries & 140 & $1,068 \mid 2,639$ & $12 \%$ \\
\hline Field Vegetables & 113 & $845 \mid 2,088$ & $10 \%$ \\
\hline $\begin{array}{l}\text { Horse Farms, Stables, and Riding } \\
\text { Facilities }\end{array}$ & 46 & $305 \mid 754$ & $4 \%$ \\
\hline Beef Cattle & 45 & $462 \mid 1,142$ & $5 \%$ \\
\hline Nurseries and Tree Farms & 35 & $233 \mid 576$ & $3 \%$ \\
\hline Specialty Crops & 23 & $154 \mid 381$ & $2 \%$ \\
\hline Dairy Farms & 18 & $456 \mid 1,127$ & $5 \%$ \\
\hline Poultry Farms & 16 & $92 \mid 227$ & $1 \%$ \\
\hline Specialty Livestock & 16 & $60 \mid 148$ & $1 \%$ \\
\hline Greenhouse Operations & 15 & $140 \mid 346$ & $2 \%$ \\
\hline $\begin{array}{l}\text { Agritourism and/or Crop Preparation } \\
\text { or Processing }\end{array}$ & 9 & $83 \mid 205$ & $1 \%$ \\
\hline Sheep and/or Goat Farms & 8 & $33 \mid 82$ & $0 \%$ \\
\hline Total & 710 & $5865 \mid 14,493$ & $67 \%$ \\
\hline
\end{tabular}

British Columbia [B.C.] Ministry of Agriculture and Lands. (2005). City of Surrey agricultural land use inventory 2004. Victoria, B.C.: Author. Retrieved from http://www.surrey.ca/

mittee, 2004). The Surrey Economic Development Strategy states that "Surrey's agricultural land deserves continued protection as part of creating a more sustainable region that can meet a share of its food needs locally. This requires a long-term vision and commitment in view of increased pressure to convert agricultural land to other uses" (City of Surrey, 2008b, p. 26). To this end the municipality enacted a unique policy in 2004 that requires placing two units of land of comparable quality into the ALR for every one removed (Policy for Considering Applications for Exclusion of Land from the Agricultural Land Reserve, Policy 0-51) (City of Surrey, 2004). This policy has greatly curtailed ALR land withdrawal within Surrey. Despite the municipality's commitment to farming and food systems, however, virtually all ALR land is valued well above that commensurate with any agricultural use, often at prices exceeding CA $\$ 250,000$ per hectare (Condon et al., 2010). ALR lands at the urbanALR interface are reported to be valued at CA $\$ 2$ million or more per hectare. Much ALR land is owned in speculation. Other ALR lands are purchased for "rural residences" and estates, including "hobby" farms and farms used for tax abatement purposes (Boyd, 1998; Stobbe, Cotteleer, \& van Kooten, 2009). In Surrey, evidence suggests that virtually no agricultural land is bought or sold for agriculture (Mullinix, Fallick, \& Dorward, 2012).

Recognizing that a significant quantity of Surrey ALR lands are extensively subdivided and held in speculation, and that such disposition often leads to non-agricultural use and land degradation, the municipality sought to curtail ALR land misuse. It sought to do so by identifying and understanding the nature of its ALR lands that were underutilized for agriculture and assessing their potential to be used for agriculture and thus to contribute to the local food system and economy. Understanding the nature and potential of these ALR lands is seen as a first step to create strategies and programs to utilize these lands for agricultural purposes and to curtail resource diminution. As such it was the objective of our study to:

1. Identify historic trends and patterns of Surrey ALR land loss;

2. Ascertain the quantity and qualities of the city's underutilized ALR lands;

3. Estimate the local food production potential of these lands if used for smallscale agriculture;

4. Estimate the income-generation potential of these lands if used for small-scale agriculture; and

5. Estimate the job-creation potential of small-scale agricultural operations on these lands. 


\section{Materials and Methods}

\section{Assessment of ALR Land Loss}

To identify historic patterns and trends of ALR land loss in Surrey between 1973 (ALR inception) and 2010, we reviewed and evaluated exclusion application documents held at the Agricultural Land Commission (ALC - the independent administrative tribunal responsible for administering the ALR in support of agriculture and adjudication of exclusion and nonfarm use applications). We also compared Surrey historical zoning maps to contemporary maps.

Assessment of Currently Underutilized ALR Lands At the time of this study (2010-11) the most recent City of Surrey land use data came from an agricultural land use inventory completed by the Ministry of Agriculture and Lands in 2004 (British Columbia Ministry of Agriculture and Lands, 2005). That inventory indicated that 669 ALR parcels composing 7,500 hectares (18,533 acres) (33\% of Surrey's ALR) were underutilized for agriculture. Eightythree parcels we could not locate were excluded from analysis. To assess how much of the land deemed underutilized in 2004 remained underutilized in 2011, we conducted an inventory of the identified parcels. Using a combination of roadside visual inspection and aerial photography interpretation, the following key data were collected for each:

- The parcel's primary land use;

- A description of any permanent structures present on the parcel (e.g., homes, outbuildings, driveways, etc.), and estimation of the portion of the property they occupied as a percentage of the whole parcel;

- The portion of the parcel available for agriculture-related activities (ARAs), recorded as a percentage of the whole;

- The general type of ARAs the parcel had potential to support as standardized into two categories:

1. Soil-based agriculture, or

2. Structure-based agriculture (including greenhouse/hoop house, raised bed, aquaculture, apiculture, or livestock barn), and/or food-system services (those services required to support small-scale local agriculture, including preproduction and production services, post-harvest services, and distribution and supply services).

This determination was based upon an assessment of the parcels' land cover, arable soil availability, proximity to major intersections, and current use(s). In general, land with an available soil resource was considered to have potential for any type of ARA, and land that was paved or had an otherwise degraded soil base was considered to have potential for structurebased agriculture or food-system services.

- The type of remediation necessary to make the parcel available for the selected ARAs was standardized into the following categories: change of use (from nonproduction to production), land clearing (tree and brush removal followed by tillage), structure reclamation or development (for structurebased agriculture), field preparation (mowing followed by tillage), or minimal to none (essentially ready for farming).

\section{Calculation of Economic and Job Creation Potential}

To estimate the potential of Surrey's underutilized ALR lands to contribute to the local economy via income generation and job creation if brought into small-scale, human-intensive, direct-market agriculture, we evaluated 12 scenarios. Scenarios were composed of three land apportionments: 0.4 hectare (1 acre) of underutilized ALR land; City of Surrey-owned underutilized ALR land (113 hectares or 279 acres), and all underutilized ALR land within Surrey (1352 hectares or 3,341 acres), and four production schemes:

\section{- Scheme 1: Highly diversified crops and products}

Production of 29 fruit and vegetable crops, honey, and two small-animal products: apple, asparagus, beet, bell pepper, broccoli, Brussels sprout, cabbage, carrot, 
cauliflower, Chinese cabbage, cucumbers, eggs, garlic, honey, hazelnut, kale, lamb, lettuce, pak choy, pear, green bean, potato, pumpkin, radish, snow pea, spinach, sweet corn, table grape, turnip, tomato, yellow onion, and zucchini.

\section{- Scheme 2: Labor-intensive crops} Production of 10 highly labor-intensive crops: spinach, carrot, snow pea, turnip, tomato, apple, beet, garlic, radish, bell pepper.

\section{- Scheme 3: Highly profitable crops} Production of ten highly profitable crops: spinach, pak choy, snow pea, Chinese cabbage, beet, pumpkin, cabbage, radish, turnip, carrot.

\section{- Scheme 4: Extensively consumed crops and products}

Production of 10 extensively consumed products: potato, eggs, apple, lettuce, onion, tomato, carrot, cabbage, table grape, cucumber.

Crop-specific production cost, labor cost, and yield data were obtained from published enterprise budgets. Every effort was made to obtain and use the most up-to-date enterprise budgets pertaining to southwest British Columbia (Beale, Dill, \& Johnson, 2008; B.C. Ministry of Agriculture and Lands, 2005, 2006, 2008a, 2008b, B.C. Ministry of Agriculture and Lands, Sustainable Agriculture Management Branch, 2009; B.C. Ministry of Agriculture, Fisheries and Food, 1993, 2001a, 2001b, 2002; Grimsrud, 1998; Gunner, 1993, 1994; Seavert, Andrews, Bubl, McReynolds, \& Freeborn, 2007). In instances where such budgets were not available (the case for five crops), we selected enterprise budgets from other locales, including Oregon, Maryland, and the B.C. Okanagan Valley. Fixed costs in the enterprise budgets we used were based on larger operations and were not easily proportioned to our smallest land allocation scenario. For that reason, for the 0.4 hectare (1 acre) farm scenario analysis we increased fixed costs from those used for all other scenarios in recognition that very small farms can expect to incur higher per-acre fixed costs than larger operations. When U.S. enterprise budgets were used, we converted monetary values based on the annual exchange rate per the Bank of Canada (2013). A fixed cost per acre of $C A \$ 1,000$ was included for land rent. This value is considered high in light of our conversations with small-scale farmers in the region, and published approximations of lease rates for comparable agriculture uses (Koopmans, 2010).

Recognizing the inherent variability in farming yields and wanting to have higher levels of confidence in our calculations, we decreased enterprise budget yield values by 15 percent and increased costs of production values by 10 percent, after inflation adjustment.

Field labor requirements were reported in a variety of formats in the enterprise budgets, so it was necessary to convert to a standard labor hour unit. If the enterprise budget indicated the total number of hours needed to produce the crop, these values were used. If field labor costs were reported as piece rate, we derived total labor hours by assuming a CA $\$ 12 /$ hour base wage rate and dividing labor costs by the hourly wage. Labor hours for each scenario were converted to full-time equivalent-field labor (FTEFL) units based on 40 hours per week for 48 work weeks per year. Because small-scale, human-intensive farming operations require management to develop the business and oversee production, processing, direct marketing, and other tasks, and because the enterprise budgets used to estimate farm labor requirements did not generally include these functions, we included a "full time equivalent-owner/operator" (FTEOO) category in the estimate of job creation and eliminated management as a cost. Further, we assumed owner/operators would derive remuneration from net farm income. Based on the demands of small-scale, human-intensive, direct-market production agriculture, we assumed one FTEOO was required per five acres in production.

Job creation potential was expressed as Full Time Equivalent Total (FTE Total) and calculated as follows:

$$
\text { FTE Total }=F T E F L+F T E O O
$$

For this study we used a static price structure. We did not attempt to calculate the changes in 
price that may result from an increase in supply, and we assumed that additional produce brought to market would be bought by consumers willing to pay for locally grown produce at the prices used. We also assumed that farmers could sell 100 percent of their products via direct market channels at prices similar to those currently obtained at farmers' markets or retail. We did not account for possible shrinkage between field and sales. In 2009 we surveyed pricing structures at regional farmers' markets and in 2011 did the same at Surrey grocery stores. These data were used to estimate a direct market price, expressed in Canadian dollars (CA\$) per pound or per dozen, for each of the 29 crops and three animal products used in our analysis; 2009 data were adjusted to 2011 dollars using the Consumer Price Index.

Prices used in our analysis were chosen preferentially in the following order:

1. "Farmers' market" prices were used when available; 44 percent of the prices we used are from local farmers' markets.

2. Where farmers' market prices were not available, we used "local" product prices at retail stores.

3. Where local product prices were not available, we used "local, organic" product prices at retail stores.

4. Where local, organic, product prices were not available, we used "organic" retail prices.

In instances where more than one preferred pricing data point was available (e.g., three sources for local, organic cabbage), an average was calculated. Prices used (table 2) were considered representative of that which small-scale farmers could expect when direct marketing high quality, local produce.
Table 2. Crop Prices Used in Calculation of Economic Potential of Underutilized Agricultural Land Reserve Lands in Surrey, B.C.

\begin{tabular}{|c|c|c|c|}
\hline & Crop & Pricea & Price Type \\
\hline \multirow{25}{*}{ 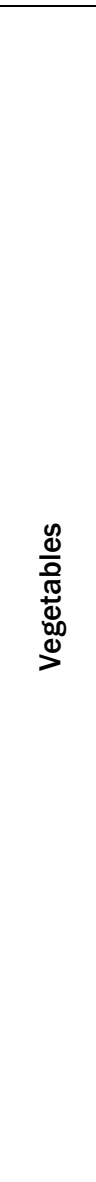 } & Asparagus & $\$ 4.98$ & Organic \\
\hline & Beet & $\$ 2.88$ & Farmers' Market \\
\hline & Bell Pepper & $\$ 3.98$ & Local, Organic \\
\hline & Broccoli & $\$ 2.36$ & Farmers' Market \\
\hline & Brussel Sprout & $\$ 1.98$ & Local, Organic \\
\hline & Cabbage & $\$ 1.68$ & Farmers' Market \\
\hline & Carrot & $\$ 2.33$ & Farmers' Market \\
\hline & Cauliflower & $\$ 3.67$ & Farmers' Market \\
\hline & Chinese Cabbage & $\$ 1.68$ & $\mathrm{~b}$ \\
\hline & Cucumber & $\$ 2.36$ & Farmers' Market \\
\hline & Garlic & $\$ 9.43$ & Farmers' Market \\
\hline & Green Bean & $\$ 3.99$ & Local, Organic \\
\hline & Kale & $\$ 4.00$ & Organic \\
\hline & Lettuce & $\$ 1.31$ & Local, Organic \\
\hline & Pak Choy & $\$ 3.98$ & Farmers' Market \\
\hline & Potato & $\$ 1.93$ & Farmers' Market \\
\hline & Pumpkin & $\$ 1.70$ & Farmers' Market \\
\hline & Radish & $\$ 2.48$ & Local, Organic \\
\hline & Snow Pea & $\$ 7.98$ & Organic \\
\hline & Spinach & $\$ 7.98$ & Organic \\
\hline & Sweet Corn & $\$ 1.04$ & Unknown \\
\hline & Tomato & $\$ 1.70$ & Farmers' Market \\
\hline & Turnip & $\$ 1.24$ & Average \\
\hline & Yellow Onion & $\$ 1.09$ & Average \\
\hline & Zucchini & $\$ 1.70$ & Farmers' Market \\
\hline \multirow{3}{*}{ 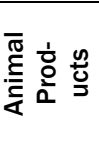 } & Egg Production & $\$ 6.14$ & Average \\
\hline & Honey & $\$ 7.27$ & Local \\
\hline & Lambc & $\$ 8.00$ & Local \\
\hline \multirow{4}{*}{ 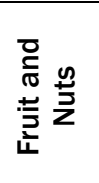 } & Apple & $\$ 1.98$ & Farmers' Market \\
\hline & Hazelnut & $\$ 14.02$ & Average \\
\hline & Pear & $\$ 2.35$ & Farmers' Market \\
\hline & Table Grape & $\$ 3.13$ & Farmers' Market \\
\hline
\end{tabular}

Average indicates that an average price was derived based on collected data.

a Price of eggs is per dozen. All other prices indicated are prices per pound.

b Prices for cabbage were used as a proxy for Chinese Cabbage.

c The Farmers Market price indicated for lamb is for the cut dressed weight and was gathered in an interview with a local lamb producer who sells through direct marketing channels.
Calculation of Food Production and Consumption Satisfaction Potential

Annual per-capita consumption rates were derived 
from Statistics Canada and USDA food disappearance data (B.C. Ministry of Agriculture and Lands, 2006; Conner, Becot, Hoffer, Kahler, Sawyer, \& Berlin, 2013; Desjardins, MacRae, \& Schumilas, 2010; Grewal \& Grewal, 2011; Statistics Canada, 2010; U.S. Department of Agriculture, Economic Research Service, 2011). To estimate potential of underutilized lands to produce foods sufficient to satisfy Surrey's food consumption over 6 months of the year the following formulas were used:

Total 6 Month Food Consumption in Surrey

$=[$ Annual Per Capita Consumption $\div 2]$ $\times 465,150$

and;

Acres Needed to Satisfy $100 \%$ of Surrey's 6 Month Food Consumption $=$

[Annual Per Capita Food Consumption $\div$ 2] Yield/Acre

and;

Potential of Land to Satisfy Surrey's 6 Month Consumption of Selected Food $=$

Acres of Land Available

Acres Needed to Satisfy $100 \%$ of Surrey's 6 Month Consumption of Selected Foods

\section{Results and Discussion}

\section{Assessment of ALR Land Loss}

We reviewed all available records of ALR land exclusion and change-of-use applications, approved and denied. In 2006, the ALC launched an online archive of Commission decisions on ALR applications, which contains files associated with applications made for Surrey properties from 2006 through 2010. These included 14 applications for nonfarm use; nine applications for transportation, utility, and recreational use; six applications for subdivision; one application to deposit fill; and one joint application for exclusion and inclusion that would result in a net gain to the ALR area. Records for these applications generally included copies of ALC staff reports with information about the nature of the application and the subject property, minutes from the ALC meeting held to discuss and decide on the application, and a copy of the final decision letter sent to the applicant. Other supporting documentation, including the applicant's submission and rationale for making the request, was in most cases not available in these online records.

For records of applications that predate 2006, only hard-copy archive files were available. Despite our interest in applications of all types, ALC staff were only able to retrieve those archive files associated with exclusion applications from 1973 to 2005. Applications for nonfarm use, to deposit fill or remove soil, and for transportation, utility, and recreational trail use were not available. Due to this limitation, it was only possible to complete an historical analysis of exclusion applications; other application types were not analyzed. Twenty-eight applications for exclusion were reviewed in hardcopy format at the ALC.

A total of 29 exclusion applications were made in Surrey over the 37-year study period, 10 of which were approved and nine of which were approved in part or with conditions. As a result, 95 hectares (235 acres) were lost from the ALR, or about $1 \%$ of Surrey's total ALR land base. In comparison, Metro Vancouver lost 9\% of its ALR in approximately the same timeframe (Provincial Agricultural Land Commission, 2011).

Although the Surrey rate of approval (66\%) seems relatively high, it was noted that all applications for exclusion occurred before December 2003, the date on which Surrey's Policy O-51 (two acres for one policy) came into effect. Since, there are no records of exclusion applications being made for ALR land in Surrey. It would appear that this policy has effectively put a moratorium on the exclusion of land, although its effect on the rate of application for nonfarm use, subdivision, soil deposition, transportation, or boundary adjustments could not be measured due to a lack of data about these types of applications before the bylaw came into effect.

A significant challenge to the intended research stemmed from the fact that historical records related to ALR applications were either incomplete or, in the case of subdivision or nonfarm use records, unavailable. From both online records and 
hard-copy archives, we made every attempt to collect comprehensive information related to the application, the parcel affected, the City of Surrey's recommendations, and the ALC's decision-making process. In many instances, however, records were incomplete and we were thus unable to retrieve information related to all of these factors. These data gaps made objective analysis difficult and the identification of consistent trends impossible. Without complete information it proved impossible to comprehensively and conclusively identify the determinants of ALR land loss and change.

We were, however, able to locate and map properties for which exclusion applications were made between 1973 and 2010. In so doing we noted a seemingly significant "edge effect" in that all exclusion applications (both successful and unsuccessful) were found to have occurred on ALR properties proximal to the ALR- urban interface. Although this suggests that the edge is most at risk to exclusion, there has not been a single successful exclusion application made since the passing of Policy O-51 in 2004. Anecdotal information from local real estate agents revealed that current land values are higher at the edge, which indicates that these properties may be subject to speculative valuation or seen as suitable sites for nonfarm use, though not necessarily via exclusion (Mullinix et al., 2012; Penner, 2008).

\section{Assessment of Currently Underutilized ALR Lands}

While exclusion of ALR lands seems to pose only a minor threat to the integrity of the municipality's agricultural land base, our analysis revealed a more troubling dynamic occurring inside the ALR: the high incidence of its use for non-agricultural purposes. Our analysis revealed that at least 556 parcels remained underutilized for agriculture in 2011, amounting to 2,446 hectares or 27 percent of Surrey's ALR. These parcels underutilized for agriculture are typically small in size, with 50 percent being 2.4 hectares (5.9 acres) or smaller and 78 percent 5 hectares (12 acres) or smaller. While the majority of underutilized parcels $(90 \%)$ are privately owned, a small number are owned by public institutions including the City of Surrey, the Surrey School Board, the provincial government, and the BC Hydro and Power Authority (BC Hydro). Most of these parcels are currently public parks with varying levels of development. None of the underutilized parcels is federally owned.

Some parcels within the underutilized ALR land are largely undeveloped and thus potentially usable for production agriculture in their entirety. Not all parcels, however, are necessarily available or suitable for agriculture-related activities. Buildings, residences, or other structures are typically found on ALR parcels used for commercial, industrial, institutional, and residential purposes. These structures, though technically impermanent, effectively render portions of each property not amenable to agriculture or food-system services in the near future. We considered the portion of underutilized land occupied by structures, calculated to be 334 hectares ( 825 acres), to be permanently alienated from agriculture, and so subtracted that amount from our estimate of total underutilized land area. Based on a lack of information regarding the feasibility and cost of their reclamation, 531 hectares (1,312 acres) of Surrey ALR land currently occupied by golf courses was also deemed permanently alienated to agriculture and subtracted from the total inventory of underutilized ALR. Likewise, 144 hectares (356 acres) of land in other non-agricultural uses (including water management areas, wildlife management areas, and transportation and communication corridors) were considered unlikely to be utilized for agriculture because they support important ecosystem or infrastructure services that are essential for Surrey's urban and agricultural communities; their area was subtracted from the total underutilized area. Thus we were able to conservatively estimate that 1,351 hectares $(3,338$ acres) of Surrey's currently underutilized ALR land could be used for small-scale, human-intensive agriculture. Five hundred hectares (1,236 acres) of this land would require reclamation such as change of use, logging, and brush clearing.

\section{Calculation of Income Generation and Job Creation Potential}

Our first scenario, 0.4 hectare (one acre), is representative of a single, very small-scale farm. Many beginning, direct market, peri-urban farmers enter the industry farming at this or a similar scale (Mullinix et al., 2012). Our analysis indicates that 
farms of this scale can employ between 1 and 1.29 people full time, and generate up to CA $\$ 36,989$ annually in return to the owner/operator. The average income in Surrey in 2006 was CA $\$ 32,733$ (City of Surrey, 2008c). Crop choice greatly affects farm profitability at this scale of production, as revenue potential for the "10 most valuable crops or animal products" scenario is more than double that of the " 29 crops and 3 animal products" scenario (table 3). Because we increased, and likely overestimated, fixed costs for the 0.4 hectare scenarios, we may have underestimated potential net revenue, but in so doing offer a more conservative estimation. The figures generated in this analysis corroborate anecdotal financial information gathered in interviews with small-scale farmers in the Surrey area, and other reports (Mullinix et al., 2012; Stobbe et al., 2010).

Our second suite of land and production scenarios was calculated for the utilization of all underutilized ALR lands owned by the City of Surrey (113 hectares or 279 acres). If these lands were brought into small-scale agricultural production, they would have the potential to contribute over CA $\$ 15$ million in gross revenue to Surrey's economy and create between 100 and 136 full-time jobs (table 4).

We recognize that many ideas for the use of this land already exist; this analysis provides an assessment of what would be possible in the near future if the City of Surrey were to take a progressive and active role in supporting new and small-scale farmers in the municipality, and make municipally owned land available to them for agriculture. In the future, cities like Surrey may be compelled to procure agriculture lands for such a purpose (Condon et al, 2010).

Our final scenario of land allocation and production analyzes the potential of all underutilized ALR parcels in the City of Surrey $(1,351$ hectares or 3,338 acres) if brought into agricultural production under the same four cropping alternatives (table 5). This includes land that is both privately owned and owned by the City of Surrey. If all 1,351 hectares (3,338 acres) of land currently underutilized for agriculture were brought into production, they would have the potential to contribute over CA $\$ 186$ million in gross receipts to Surrey's agriculture sector. This would more than double the current economic magnitude of the industry. The enterprises on this land could employ between 1,188 and 1,623 full-time employees.

\section{Calculation of Food Production and Consumption Satisfaction Potential}

Our analysis reveals that Surrey's underutilized land has the capacity to make significant contributions to the community's food supply. Taking into

Table 3. Economic and Job Creation Potential of 0.4 ha ( 1 acre) of Underutilized ALR Land in Surrey, B.C., Under Four Production Schemes

\begin{tabular}{|c|c|c|c|c|c|}
\hline & & \multicolumn{2}{|c|}{ Potential Revenue Generated (all CA\$) } & \multicolumn{2}{|c|}{ Potential Jobs Created } \\
\hline & & Gross Revenue & $\begin{array}{c}\text { Return to } \\
\text { Owner/Operator }\end{array}$ & FTEFL* & FTEOO* \\
\hline \multirow{4}{*}{ 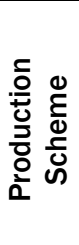 } & 29 Crops, Products, and Honey a & $\$ 34,779$ & $\$ 19,182$ & 0.16 & 1 \\
\hline & 10 Most Labor-Intensive Crops ${ }^{b}$ & $\$ 43,817$ & $\$ 23,578$ & 0.29 & 1 \\
\hline & 10 Most Profitable Crops ${ }^{c}$ & $\$ 54,813$ & $\$ 36,968$ & 0.23 & 1 \\
\hline & $\begin{array}{l}10 \text { Most Highly Consumed Crops } \\
\text { and Products d }\end{array}$ & $\$ 31,165$ & $\$ 14,443$ & 0.18 & 1 \\
\hline
\end{tabular}

a Apples, asparagus, beet, bell pepper, broccoli, Brussels Sprout, cabbage, carrot, cauliflower, Chinese cabbage, cucumber, garlic, green bean, lettuce, hazelnut, kale, pak choy, pear, potato, pumpkin, radish, snow pea, spinach, sweet corn, table grape, turnip, tomato, yellow onion, zucchini, and honey. All crops grown on one-twenty-ninth acre.

b Tomato, snow pea, turnip, apple, beet, garlic, carrot, radish, bell pepper, potato. All grown on one-tenth acre.

c Spinach, pak choy, snow pea, Chinese cabbage, beet, pumpkin, cabbage, radish, turnip, carrot. All grown on one-tenth acre.

d Potato, apple, lettuce, yellow onion, tomato, carrot, cabbage, table grape, cucumber, bell pepper. All grown on one-tenth acre.

* FTEFL (full-time equivalent-field labor) and FTEOO (full-time equivalent-owner/operator) 
Table 4. Economic and Job Creation Potential of 113 ha (279 acres) of Municipally Owned Underutilized ALR Land in Surrey, B.C., Under Four Production Schemes

\begin{tabular}{|c|c|c|c|c|c|}
\hline & & \multicolumn{2}{|c|}{ Potential Revenue Generated (all CA\$) } & \multicolumn{2}{|c|}{ Potential Jobs Created } \\
\hline & & Gross Revenue & $\begin{array}{c}\text { Return to } \\
\text { Owner/Operator }\end{array}$ & FTEFL * & FTEOO* \\
\hline \multirow{4}{*}{ 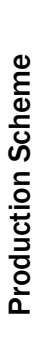 } & 29 Crops, 2 Animal Products, and Honey a & $\$ 9,454,419$ & $\$ 6,110,457$ & 44 & 56 \\
\hline & $\begin{array}{l}10 \text { Most Labor Intensive Crops and Animal } \\
\text { Products }{ }^{b}\end{array}$ & $\$ 12,268,898$ & $\$ 7,715,140$ & 80 & 56 \\
\hline & $\begin{array}{l}10 \text { Most Profitable Crops and Animal } \\
\text { Products }{ }^{c}\end{array}$ & $\$ 15,347,607$ & $\$ 11,464,525$ & 66 & 56 \\
\hline & $\begin{array}{l}10 \text { Most Highly Consumed Crops and } \\
\text { Animal Products d }\end{array}$ & $\$ 8,511,718$ & $\$ 4,871,498$ & 48 & 56 \\
\hline
\end{tabular}

a Apples, asparagus, beet, bell pepper, broccoli, Brussels Sprout, cabbage, carrot, cauliflower, Chinese cabbage, cucumber, garlic, green bean, lettuce, hazelnut, kale, pak choy, pear, potato, pumpkin, radish, snow pea, spinach, sweet corn, table grape, turnip, tomato, yellow onion, zucchini, and honey. All crops grown on one-twenty-ninth acre.

b Tomato, snow pea, turnip, apple, beet, garlic, carrot, radish, bell pepper, potato. All grown on one-tenth acre.

c Spinach, pak choy, snow pea, Chinese cabbage, beet, pumpkin, cabbage, radish, turnip, carrot. All grown on one-tenth acre.

d Potato, apple, lettuce, yellow onion, tomato, carrot, cabbage, table grape, cucumber, bell pepper. All grown on one-tenth acre.

* FTEFL (full-time equivalent-field labor) and FTEOO (full-time equivalent-owner/operator)

Table 5. Economic and Job Creation Potential of 1351 ha (279 acres) of Underutilized ALR land in Surrey, B.C., Under Four Production Schemes

Potential Revenue Generated (all in CA\$)

Potential Jobs Created

Return to

Gross Revenue Owner/Operator

FTEFL * FTEOO*

\begin{tabular}{|c|c|c|c|c|c|}
\hline \multirow{4}{*}{ 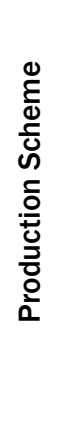 } & 29 Crops, 2 Animal Products, and Honey a & $\$ 113,440,053$ & $\$ 72,922,342$ & 520 & 668 \\
\hline & $\begin{array}{l}10 \text { Most Labor-Intensive Crops and Animal } \\
\text { Products }{ }^{b}\end{array}$ & $\$ 146,350,426$ & $\$ 92,003,041$ & 955 & 668 \\
\hline & $\begin{array}{l}10 \text { Most Profitable Crops and Animal } \\
\text { Products }^{c}\end{array}$ & $\$ 183,075,030$ & $\$ 136,714,466$ & 783 & 668 \\
\hline & $\begin{array}{l}10 \text { Most Highly Consumed Crops and } \\
\text { Animal Products }{ }^{d}\end{array}$ & $\$ 101,532,639$ & $\$ 58,092,610$ & 571 & 668 \\
\hline
\end{tabular}

a Apples, asparagus, beet, bell pepper, broccoli, Brussels Sprout, cabbage, carrot, cauliflower, Chinese cabbage, cucumber, garlic, green bean, lettuce, hazelnut, kale, pak choy, pear, potato, pumpkin, radish, snow pea, spinach, sweet corn, table grape, turnip, tomato, yellow onion, zucchini, and honey. All crops grown on one-twenty-ninth acre.

b Tomato, snow pea, turnip, apple, beet, garlic, carrot, radish, bell pepper, potato. All grown on one-tenth acre.

c Spinach, pak choy, snow pea, Chinese cabbage, beet, pumpkin, cabbage, radish, turnip, carrot. All grown on one-tenth acre.

d Potato, apple, lettuce, yellow onion, tomato, carrot, cabbage, table grape, cucumber, bell pepper. All grown on one-tenth acre.

* FTEFL (full-time equivalent-field labor) and FTEOO (full-time equivalent-owner/operator) 
Table 6. Land Needed to Satisfy Consumption Rates for Population of Surrey, B.C.

\begin{tabular}{|c|c|c|c|}
\hline Crop & $\begin{array}{l}\text { Consumption } \\
\text { Per Person } \\
\text { (Ib./year) }\end{array}$ & $\begin{array}{l}\text { Consumption of } \\
\text { Total Surrey } \\
\text { Population } \\
\text { (lb./year) } \\
\end{array}$ & $\begin{array}{c}\text { Hectares I Acres } \\
\text { to Produce } 6 \text { Month } \\
\text { Supply for Surrey } \\
\text { Population } \\
\end{array}$ \\
\hline Asparagus & 1.5 & 717,835 & 38 | 94 \\
\hline Beet & 1.4 & 656,307 & $8 \mid 20$ \\
\hline Bell Pepper & 9.7 & $4,501,853$ & 115 | 284 \\
\hline Broccoli & 6.4 & $2,963,634$ & $90 \mid 222$ \\
\hline Brussels Sprout & 0.3 & 143,567 & $3 \mid 7$ \\
\hline Cabbage & 11.5 & $5,332,491$ & $40 \mid 99$ \\
\hline Carrot & 15.9 & $7,373,194$ & $74 \mid 183$ \\
\hline Cauliflower & 5.7 & $2,635,481$ & 78 | 193 \\
\hline Chinese Cabbage & 1.9 & 871,657 & $5 \mid 12$ \\
\hline Cucumber & 10.5 & $4,881,280$ & 79 | 195 \\
\hline Garlic & 1.0 & 451,211 & $31 \mid 77$ \\
\hline Green Bean & 2.1 & 984,460 & 94 | 232 \\
\hline Honey & 1.4 & 666,561 & $\mathrm{n} / \mathrm{a}$ \\
\hline Kale & 0.3 & 139,545 & $83 \mid 205$ \\
\hline Lamb & 2.6 & $1,199,810$ & 13 | 32 \\
\hline Lettuce & 22.0 & $10,234,280$ & 135 | 334 \\
\hline Pak Choy & 1.1 & 511,665 & $8 \mid 20$ \\
\hline Pear & 4.8 & $2,245,799$ & $80 \mid 198$ \\
\hline Pumpkin & 3.7 & $1,721,055$ & $14 \mid 35$ \\
\hline Radish & 1.4 & 646,052 & $8 \mid 20$ \\
\hline Snow Pea & 0.7 & 317,898 & 7 | 17 \\
\hline Spinach & 1.4 & 666,561 & 12 | 30 \\
\hline Sweet Corn & 7.1 & $3,291,788$ & $68 \mid 68$ \\
\hline Tomato & 16.4 & $7,619,309$ & 79 | 195 \\
\hline Turnip & 2.7 & $1,240,830$ & $8 \mid 20$ \\
\hline Yellow Onion & 21.6 & $10,059,949$ & 73 | 180 \\
\hline Zucchini & 4.0 & $1,860,600$ & 45 | 111 \\
\hline
\end{tabular}

Hectares | Acres required to produce $100 \%$ of Surrey's consumption of listed crops for 6 months/year

Percent of Surreys' 6-month/year consumption of listed crops that could be produced on underutilized ALR
1,288 | 3,183

$105 \%$
Surrey's limited infrastructural capacity for processing and storage of crops, we based our calculations on food supply for six months of the year, which is the approximate growing season of most of these crops in Surrey's temperate coastal climate. Our analysis showed that Surrey's underutilized ALR lands could satisfy 100 percent of the municipality's consumption of 27 crops and animal products for six months of the year, if the land were used exclusively for the production of those products (table 6 ).

\section{Conclusion}

When we initiated this study, we thought that an assessment of the loss of Surrey's agricultural land from the ALR would yield useful information for planners and policy-makers involved in agriculture and land use planning, and who are seeking to protect the agricultural land base and enhance local agriculture in the municipality (American Planning Association, 2007; Morgan, 2009; Pothukuchi \& Kaufman, 2000). The first Chairperson of the Agricultural Land Commission stated that the ALR was designed to protect B.C.'s agricultural land because, "in the face of increasing land use pressures, local governments were unable or unwilling to hold the line against 
rezoning agricultural lands to purportedly 'higher and better uses"' (Runka, 2006, p. 1)). We assumed that Surrey's ALR lands were under significant threat of exclusion from the ALR through a variety of pressures including rapid urbanization, speculation from developers and non-agricultural interests, and expropriation for transportation and infrastructure requirements. Surprisingly, however, historical records revealed that very few Surrey parcels have, in fact, been lost to the ALR as a result of exclusion applications since 1973.

Protecting farmland, however, does not automatically or necessarily equate to utilization of those resources for agriculture (Pynn, 2008) or result in an economically robust agriculture sector that contributes to a region's economic health and vitality (Hamilton, 2011) and produces food for the local populace. If governments and citizens choose to invest in innovative agriculture on protected land, then the resulting local-regional food systems can increase business innovation and entrepreneurship, result in sector-specific economic growth, foster regional economic development, and support employment (Illinois Local and Organic Food and Farm Task Force, 2009; Meter \& Rosales, 2001; O’Hara, 2011; Swenson, 2011). Direct marketing channels, such as farmers' markets and farm-gate sales, are identified as especially significant contributors, as these systems allow most, if not all, of sales revenue to be retained locally (Farmers Markets Canada, 2009; Pirog \& McCann, 2009; Stobbe et al., 2009). Our study details the revenue, job creation, and food production potential of Surrey's underutilized lands if devoted to this type of agriculture.

We do not mean to suggest that all of the available underutilized ALR lands necessarily should be brought into agricultural production or that to the extent they were brought into production that precisely the income generation, job creation, or food provision levels presented herein would necessarily result. Rather, our assessment, based on the best data available, is meant to elucidate that the food production and economic potential of Surrey's underutilized ALR land is not trivial. In light of this, the value of Surrey's underutilized ALR parcels, many of them very small, should not be dismissed or overlooked by the City of Surrey or its residents. They hold immense, immediate value from food-production and economiccontribution perspectives.

Agriculturalists are astute entrepreneurs, traditionally attuned to responding to economic and regulatory signals. There is a growing recognition by agriculturalists and the broader society, reinforced by many market signals, of the emerging potential in the re-localization of food systems (Brinkley, 2012; Desjardins et al., 2010; Palan, 2005; Peters, Wilkins \& Flick, 2006; Pothukuchi \& Kaufman, 1999). However, the hegemony of the contemporary agri-food production and marketing system (Heffernan, 2005) and our economic environment in general has thus far precluded the substantial emergence of this sector. If its potential is to be fully realized, it will have to be supported and facilitated by governments, especially local governments, through policy, regulation, and programming (Ikerd, 2011; Pothukuchi, 2009; Pothukuchi \& Kaufman, 1999; Sonnino, 2009). In Surrey specifically, the transition of these lands into full agricultural utilization is not without significant policy and strategic challenges, all of which relate to two underlying problems: nonfarmer ownership of ALR land, and limited resources and support for small-scale, human-intensive, alternate market farming. As the owner of approximately 113 hectares (279 acres) of underutilized ALR land, the City of Surrey has the opportunity to immediately address some of these challenges and set an example by assuring that their own land is utilized for agriculture. This could be achieved through protective covenants on the land, agriculture landlease programs, and/or a farmland trust (Wittman, 2009). On nearby Vancouver Island, the District of Saanich rezoned a publicly owned parcel for agriculture in 2006. The district now leases that land to a registered charity that stewards it for farming by several successful small farm businesses (Haliburton Community Organic Farm, n.d.; The Land Conservancy of B.C., 2013).

For the City of Surrey, we also delineated many policy options for encouraging and supporting the use of privately owned agricultural lands for agriculture. Extensive discussion of those recommendations is not the subject of this report. However one potential, albeit likely highly controversial, 
mechanism for municipalities to minimize effective loss of zoned and/or protected agriculture lands would be the creation and enforcement of strong regulations against, and penalties for, their nonagricultural use. Surrey's zoning bylaw currently permits the use of ALR parcels for a wide variety of non-agricultural purposes, including a number that could be prohibited under the provisions of the provincial ALC Act, such as commercial and hobby kennels and pet-breeding operations, hunting and wilderness survival training, and golf courses. To curtail speculative holding of agricultural land, municipalities could "tax" away the economic incentive for their development, by imposing development-cost levies and community amenity contribution assessments (Condon et al., 2010). Bringing forth an economic sector of this nature and magnitude will also require an extensive compliment of trained and committed agriculturists (Heinberg, 2006; Mullinix, Fallick, \& Rallings, 2011). Surrey and other municipalities could facilitate or support appropriate education and extension programming.

Though the ALR is unique to British Columbia, agricultural land use planning and restrictive agricultural land use regulation is common in North America. Equally common are issues of nonfarmer ownership and nonfarm use of agricultural land, the development of and urban encroachment upon agricultural land, and scant recognition of the economic, job creation, and food production potential of small-scale alternate market agricultural enterprises in peri-urban locales. As such this study presents a method of assessing non-agricultural use and "effective land loss" of designated peri-urban agricultural land as well as their potential to contribute more substantively to regional economies and food systems that other jurisdictions can adapt and use. In doing so we have strengthened the case for food system regionalization.

\section{References}

Agriculture and Agri-Food Canada. (2013a). Plant Hardiness Zones of Canada. Retrieved from http://atlas.agr.gc.ca/agmaf/index eng.html
Agriculture and Agri-Food Canada. (2013b). Soils of Canada. Retrieved from http://atlas.agr.gc.ca/ agmaf/index eng.html\#context=soil-sol en.xml

American Planning Association. (2007). Policy guide on community and regional food planning. Chicago, Illinois: Author. http://www.planning.org/policy/guides/ adopted/food.htm

Bank of Canada. (2013). Monthly and annual average exchange rates. Retrieved from http://www.bankof canada.ca/rates/exchange/exchange-rates-in-pdf

Beale, B., Dill, S., \& Johnson, D. (2008). 2008 Maryland vegetable enterprise budgets [Publication No. EB-371]. College Park, Maryland: Maryland Cooperative Extension, University of Maryland. http://pubs.agnr.umd.edu/Category.cfm?ID $=\mathrm{C}$

Boyd, S. (1998). Hobby farming - For pleasure or profit? [Working Paper No. 33]. Ottawa, Canada: Statistics Canada Agriculture Division. Retrieved from the AgEcon Search website: http://ageconsearch.umn. edu/bitstream/28054/1/wp000033.pdf

Brinkley, C. (2012). Evaluating the benefits of periurban agriculture. Journal of Planning Literature, 27(3), 259-269. http://dx.doi.org/10.1177/0885412211435172

British Columbia [B.C.] Ministry of Agriculture and Lands. (2005). City of Surrey agricultural land use inventory 2004. Victoria, B.C.: Author. Retrieved from http://www.surrey.ca/

B.C. Ministry of Agriculture and Lands. (2006). B.C.'s food self-reliance: Can B.C.'s farmers feed our growing population? Victoria, B.C.: Author. Retrieved from http://www.agf.gov.bc.ca/resmgmt/Food Self Reliance/BCFoodSelfReliance Report.pdf

B.C. Ministry of Agriculture and Lands. (2008a). Planning for profit: Twenty acres mixed livestock operation: Broilers, layers/ eggs, sheep, beef: full production, V ancouver Island, spring 2008. Victoria, B.C.: Author. Retrieved from http://www.agf.gov.bc.ca/busmgmt/budgets/ small scale.htm

B.C. Ministry of Agriculture and Lands. (2008b). Planning for profit: Five acre mixed vegetable operation: full production: V ancouver Island. Victoria, B.C.: Author. Retrieved from http://www.agf.gov.bc.ca/ busmgmt/budgets/small scale.htm

B.C. Ministry of Agriculture and Lands, Sustainable Agriculture Management Branch. (2009). City of Surrey agricultural overview. Victoria, B.C.: Author. Retrieved from http://www.agf.gov.bc.ca/ resmgmt/sf/agoverviews 2006census/Surrey Ag Ov.pdf 
B.C. Ministry of Agriculture, Fisheries and Food. (1993). Planning for profit: Hazelnuts, Fraser V alley, summer 1993. Victoria, B.C.: Author. Retrieved from http://www.agf.gov.bc.ca/busmgmt/budgets/herb specialty.htm

B.C. Ministry of Agriculture, Fisheries and Food. (2001a). Planning for profit: Fresh asparagus — Fraser Valley. Victoria, B.C.: Author. Retrieved from http://www.agf.gov.bc.ca/busmgmt/budgets/ vegetables.htm

B.C. Ministry of Agriculture, Fisheries and Food. (2001b). Planning for profit: Pears central axe (389 trees/acre) — Okanagan Valley. Victoria, B.C.: Author. Retrieved from http://www.agf.gov.bc.ca/ busmgmt/budgets/tree_fruits.htm

B.C. Ministry of Agriculture, Fisheries and Food. (2002). Planning for profit: Mixed tree fruit and table grape small scale operation - 5 acres, winter 2002. Victoria, B.C.: Author. Retrieved from http://www.agf.gov.bc.ca/ busmgmt/budgets/small scale.htm

B.C. Provincial Agricultural Land Commission. (2002a). How the ALR was established. Burnaby, B.C.: Author. http://www.alc.gov.bc.ca/alr/Establishing the ALR.htm

B.C. Provincial Agriculture Land Commission. (2002b). Agricultural Land Commission Act [S.B.C. 2002] Chapter 36. Burnaby, B.C.: Provincial Agricultural Land Commission.

Cantrell, P., Colasanti, K., Goddeeris, L., Lucas, S., \& McCauley, M. (2013). Food Innovation Districts: An economic gardening tool. Michigan State University Urban Planning Practicum 2012. Traverse City, Michigan: Northwest Michigan Council of Governments. Retrieved from http://www.nwm.org/food-innovation-districts

City of Surrey. (2004). Policy for considering applications for exclusion of land from the Agricultural Land Reserve (No. O-51). Surrey, B.C.: Author. Retrieved from http://www.surrey.ca

City of Surrey. (2008a). Sustainability charter: A commitment to sustainability. Surrey, B.C. Surrey, B.C.: Author. Retrieved from http://www.surrey.ca

City of Surrey. (2008b). City of Surrey Economic Development Strategy. Surrey, B.C.: Author. Retrieved from https://www.surrey.ca/files/Surrey Economic Development Strategy - FINAL VERSION.pdf
City of Surrey. (2008c). Total income fact sheet. Surrey, B.C.: Author. Retrieved from http://www.surrey.ca/files/2006-Total-Income.pdf

City of Surrey Economic Development Office. (n.d.). City of Surrey agriculture sector profile. Surrey, B.C.: City of Surrey. Retrieved from http://www.surrey.ca/ files/Agriculture_Sector_Profile_LORES.pdf

Condon, P. M., Mullinix, K., Fallick, A., \& Harcourt, M. (2010). Agriculture on the edge: Strategies to abate urban encroachment onto agricultural lands by promoting viable human scale agriculture as an integral element of urbanization. International Journal of Agricultural Sustainability, 8(1-2), 1-12. http://dx.doi.org/10.3763/ijas.2009.0465

Conner, D., Becot, F., Hoffer, D., Kahler, E., Sawyer, S., \& Berlin, L. (2013). Measuring current consumption of locally grown foods in Vermont: Methods for baseline and targets. Journal of Agriculture, Food Systems and Community Development, 3(3), 1-12. http://dx.doi.org/10.5304/jafscd.2013.033.004

Desjardins, E., McRae, R., \& Schumilas, T. (2010). Linking future population food requirements for health with local production in Waterloo Region, Canada. Agriculture and Human Values, 27(2), 129140. http://dx.doi.org/10.1007/s10460-009-9204-y

District of Maple Ridge. (2009). Maple Ridge Agricultural Plan Phase 3. Maple Ridge, B.C.: Author.

Environment Canada. (2012). National climate data and information arcbive. Retrieved from http://climate.weather.gc.ca/index_e.html

Esseks, D., Oberholtzer, L., Clancy, K., Lapping, M., \& Zurbrugg, A. (2008). Sustaining agriculture in urbanizing counties: Insights from 15 coordinated case studies. Lincoln, Nebraska: University of Nebraska-Lincoln.

Farmers' Markets Canada. (2009). National farmers' market impact study. Brighton, Ontario: Author.

Goldschmidt, W. R. (1978). As you sow: Three studies in the social consequences of agribusiness. Montclair, New Jersey: Allanheld, Osmun.

Grewal, S. S., \& Grewal, P. S. (2011). Can cities become self reliant in food? Cities, 29(1), 1-11. http://dx.doi.org/10.1016/j.cities.2011.06.003

Grimsrud, M. (1998). Planning for profit: Chinese cabbage, Fraser V alley, summer 1998 [Agdex 252-810]. Victoria, B.C.: B.C. Ministry of Agriculture and Lands. 
Gunner, A. (1993). Planning for profit: Honey production, Vancouver Island, summer 1993 [Agdex 616-810]. Victoria, B.C.: B.C. Ministry of Agriculture, Fisheries and Food.

Gunner, A. (1994). Planning for profit: Jonagold apple establishment, slender spindle-808 trees/acre, Fraser Valley, spring 1994 [Agdex 211-810]. Victoria, B.C.: B.C. Ministry of Agriculture, Fisheries and Food.

Haliburton Community Organic Farm. (n.d.). The land. Retrieved August 2, 2013, from http://haliburtonfarm.org/wp/the-land

Hamilton, G. (2011, June 11). Profits prove a tough crop to grow for B.C.'s conventional farmers. Vancouver Sun. Retrieved from http://www.canada. $\mathrm{com} /$ vancouversun/news/business/story.html?id= d0f50357-2040-45c1-a4a0-f2ac011a7a94

Heffernan, W. (2005). Understanding what is happening in our food and farming system. In K. Mullinix (Ed.), The next agricultural revolution: Revitalizing family based agriculture and rural communities (pp. 11-22. Proceedings of the Washington State Family Farm Summit. Yakima, Washington: Good Fruit Grower.

Heinberg, R. (2006, October 28). Fifty million farmers. Speech given to the E. F. Schumacher Society, Great Barrington, Massachusetts.

Ikerd, J. (2011). Land use planning for sustainable food systems. Journal of Agriculture, Food Systems and Community Development, 2(1), 3-5. http://dx.doi.org/10.5304/jafscd.2011.021.010

Illinois Local and Organic Food and Farm Task Force. (2009). Local food, farms and jobs: Growing the Illinois economy. Springfield, Illinois: State of Illinois General Assembly. Retrieved from http://www..agr.state. il.us/newsrels/taskforcereport-outside.pdf

Kent Agricultural Advisory Committee. (2004). Small lot agriculture in the District of Kent, BC. Kent, B.C.:

Municipality of Kent. Retrieved from http://www.fraserbasin.bc.ca/ Library/FVR/ report fvr small lot ag 2004.pdf

Koopmans, K. (2010). Supporting new small scale farmers in Abbotsford. Community Futures South Fraser. Retrieved from http://www.southfraser.com/ includes/documents/SupportingNewFarmersin Abbotsford.pdf

Land Conservancy of B.C., The. (2013). Haliburton Community Organic Farm [Web log post]. Retrieved August 2, 2013, from http://blog.conservancy.bc.ca/properties/agricultu $\mathrm{re} /$ programs/conservation-partners-program/ourpartners-vancouver-island/haliburton-communityorganic-farm/

Meter, K., \& Rosales, J. (2001). Finding food in farm country: The economics of farming in southeast Minnesota. St. Paul, Minnesota: Community Design Center. Retrieved from the Crossroads Resource Center website: http:/ / www.crcworks.org/ff.pdf

Metro Vancouver. (2007). 2006 census bulletin \#2, census of agriculture. Burnaby, B.C.: Metro Vancouver.

Morgan, K. (2009). Feeding the city: The challenge of urban food planning. International Planning Studies, 14(4), 341-348. http://dx.doi.org/10.1080/13563471003642852

Morton, B. (2008, May 26). BC farmers earning less. Vancouver Sun. Retrieved from http://www.canada. $\mathrm{com} /$ vancouversun $/$ news $/$ story.html?id=f1bad006 -cfcc-4eeb-bd64-60f41f6faa12

Mullinix, K., Fallick, A., \& Dorward, C. (2012). Surrey's underutilized ALR lands: An analysis of their economic and food production potential in direct market agriculture. Surrey, B.C.: Institute for Sustainable Horticulture, Kwantlen Polytechnic University. Retrieved from http://kwantlen.ca/ shared/assets/Surrey s Underutilized ALR Lands23391.pdf

Mullinix, K., Fallick, A., \& Rallings, A. (2011). The Richmond Farm School: An extension education program to prepare 21 st century urban and peri-urban agriculturists. Presentation at the annual conference of the North American Colleges and Teachers of Agriculture. University of Alberta, Edmonton, Alberta. Canada. Retrieved from http://www.kwantlen.ca/ _ shared/assets/NACTA_RFS20101.pdf

Nasssauer, J. I. (1997). Agricultural landscapes in harmony with nature. In W. Lockeretz (Ed.), $V$ isions of American Agriculture (pp. 59-73). Ames, Iowa: Iowa State University Press.

O’Hara, J. K. (2011). Market forces: Creating jobs through public investment in local and regional food systems. Cambridge, Massachusetts: Union of Concerned Scientists. Retrieved from http://www.ucsusa.org/ food and agriculture/solutions/expand-healthyfood-access/market-forces.html 
Palan, K. M. (2005). Examining awareness of and support of regional food systems in Iowa: Establishing a baseline of knowledge about regional food systems and communications preferences. Ames, Iowa: Leopold Center for Sustainable Agriculture, Iowa State University. Retrieved from http://www.leopold.iastate.edu/ pubs-and-papers /2005-01-regional-food-systems

Penner, D. (2008, May 24) Land prices outstrip economics of farming. Vancouver Sun. Retrieved from http://www.canada.com/vancouversun/ news/business/story.html?id=dbd1 f0d3-eb31440d-9704-b6f2fa1d3f65

Peters, C., Wilkins, J., \& Flick, G. W. (2006). Testing a complete-diet model for estimating the land resource requirements of food consumption and agricultural carrying capacity: The New York State example. Renewable Agriculture and Food Systems, 22(2), 145-153. http://dx.doi.org/10.1017/S1742170507001767

Pirog, R., \& McCann, N. (2009). Is local more expensive? A consumer price perspective on local and non-local foods purchased in Iowa. Ames, Iowa: Leopold Center for Sustainable Agriculture, Iowa State University. Retrieved from http://www.leopold.iastate.edu/ pubs-and-papers/2009-12-local-food-moreexpensive

Pothukuchi, K. (2009). Community and regional food planning: Building institutional support in the United States. International Planning Studies, 14(4), 349-367. http://dx.doi.org/10.1080/13563471003642902

Pothukuchi, K., \& Kaufman, J. (1999). Placing the food system on the urban agenda: The role of municipal institutions in food system planning. Agriculture and Human V alues, 16(2), 213-224. http://dx.doi.org/10.1023/A:1007558805953

Pothukuchi, K., \& Kaufman, J. (2000). The food system: A stranger to the planning field. American Planning Association Journal, 66(2), 113-124. http://dx.doi.org/10.1080/01944360008976093

Provincial Agricultural Land Commission. (2011). Annual Report 2009/10 \& 2010/11. Burnaby, B.C.: Author. http://www.alc.gov.bc.ca/publications/ Annual Report 2009-10 and 2010-11.pdf

Pynn, L. (2008, May 24). "Farmland is like an endangered species." Vancouver Sun. Retrieved from http://www2.canada.com/vancouversun/features/ food/story.html?id=3bdaff12-1537-46fd-a90a$\underline{183 \mathrm{~d} 313 \mathrm{~d} 74 \mathrm{f} 4}$
Runka, G. 2006. BC's Agricultural Land Reserve: Its historical roots. Presented at the Post World Planners Congress Seminar. Vancouver, BC. Retrieved from http://www.alc.gov.bc.ca/Reference_and_Resourc e Documents/Docs/ALR \%20Historical\%20Roots \%20-\%20Runka\%202006\%20.pdf

Seavert, C., Andrews, N., Bubl, C., McReynolds, R., \& Freeborn, J. (2007). Enterprise budget: Radishes, organic, fresh market, Willamette V alley region. Corvallis, Oregon: Oregon State University Extension Service. Retrieved from http://arec.oregonstate. edu/oaeb/files/pdf/EM8927.pdf

Sonnino, R. (2009). Feeding the city: Towards a new research and planning agenda. International Planning Studies, 14(4), 425-435. http://dx.doi.org/10.1080/13563471003642795

Statistics Canada. (2010). Food Statistics 2009 (Catalogue No. 21-020-X). Retrieved from http://www.statcan.gc.ca/pub/21-020-x/21-020x2009001-eng.htm

Stobbe, T., Cotteleer, G., \& van Kooten, G. C. (2009). Hobby farms and protection of farmland in British Columbia. Canadian Journal of Regional Science, 32(3), 393-410.

Stobbe, T., Eagle, A. J., \& van Kooten, G. C. (2010). Niche and direct marketing in the rural-urban fringe: A study of the agricultural economy in the lower mainland and Fraser Valley. BC Studies, 167, 105-134. Retrieved from http://ojs.library.ubc.ca/ index.php/bcstudies/article/view/407

Swenson, D. (2011). Measuring the economic impacts of increased fresh fruit and vegetable production in Iowa considering metropolitan demand. Ames, Iowa: Leopold Center for Sustainable Agriculture, Iowa State University. Retrieved from http://www.leopold. iastate.edu/pubs-and-papers/2011-04metropolitan-demand

U.S. Department of Agriculture, Economic Research Service. (2011). Food availability (per capita) data system. http://www.ers.usda.gov/Data/FoodConsumption

Wittman, H. (2009). Community farms in B.C.: Building local food systems for sustainable communities. Vancouver: FarmFolk/CityFolk, The Land Conservancy of B.C., and Simon Fraser University. Retrieved from http://www.farmfolkcityfolk.ca/community-farmsprogram/community-farms-in-bc/ 